\title{
Knee pain in a male patient in his 90 s caused by osteoid osteoma
}

\author{
Corrado Tagliati (ㄷ , Davide Battista, Sergio Valeriano, Giuseppe Lanni
}

Dipartimento dei Servizi, U.O.S.D. Radiologia Ospedale "San Liberatore" Atri, ASL 4 Teramo, Teramo, Abruzzo, Italy

\section{Correspondence to} Dr Corrado Tagliati; corrado.tagliati@gmail.com

Accepted 12 August 2021

\section{DESCRIPTION}

A 92-year-old man with persistent knee pain for 1 year presented to our radiology department in order to perform a CT examination prescribed by his general practitioner.

CT showed degenerative joint disease.

Moreover, a subcentimetric sclerotic lesion with adjacent round-shaped low-density area (nidus) and scarce cortical thickening was detected in the anterior distal femoral cortical bone (figure 1).

These imaging findings were consistent with osteoid osteoma (OO).

The patient responded to non-steroidal antiinflammatory drugs with significant subjective pain reduction.

$\mathrm{OO}$ is a benign bone tumour less than $1.5-2 \mathrm{~cm}$ in size. Three out of four cases occur under 25 years of age, and $\mathrm{OO}$ was very rarely reported in patients over 65 years of age. ${ }^{1}$

Somma et al reported 90 adult patients with OO, and the oldest patient was 75 years old. Hashemi reported 45 patients with $\mathrm{OO}$, and the oldest patient was 35 years old. ${ }^{2}{ }^{3}$ Campanacci et $a l^{4}$ reported 1894 cases with osteoid osteoma, and the age range was $0-68$ years.

CT is considered the best imaging technique in order to characterise $\mathrm{OO}$, and it is particularly useful when the nidus is small and the peripheral cortical sclerosis is scarce.

To the best of our knowledge, this is the first case report about an osteoid osteoma in a patient in his 90s. This case shows that knee pain in elderly patients could also be caused by a benign tumour
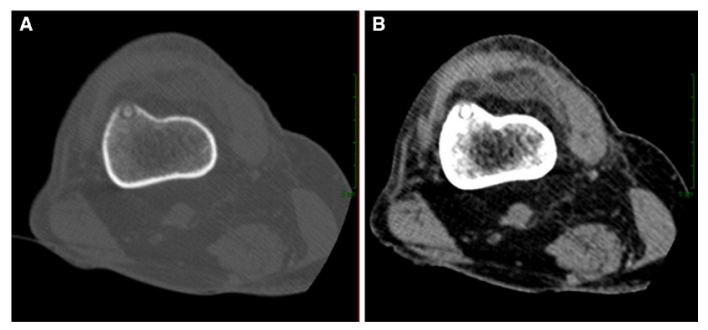

Figure 1 Multidetector $C T$ scan images with bone (A) and soft tissue (B) algorithm reconstruction that shows a cortical tibial bone density alteration, consistent with osteoid osteoma.

\section{Patient's perspective}

I would like to express my thanks to the doctors who recognised my bone lesion. In fact, I could now understand the cause of my knee pain.

\section{Learning points}

- Osteoid osteoma could be rarely diagnosed in patients in their 90 s.

- Very elderly patients with chronic knee pain could sometimes benefit from tomographic imaging such as CT.

and that osteoarthritis is not always alone at the base of this symptom. Moreover, in very elderly patients with knee pain, X-ray examination is usually the sole imaging performed. This examination is unable to recognise small lesions such as the one reported. Therefore, even very elderly patients with chronic knee pain could sometimes benefit from tomographic imaging such as CT.

Contributors CT, DB and SV were involved in the preparation of this manuscript. GL revised the manuscript for intellectual content. All authors read and approved the manuscript.

Funding The authors have not declared a specific grant for this research from any funding agency in the public, commercial or not-for-profit sectors.

Competing interests None declared.

Patient consent for publication Obtained.

Provenance and peer review Not commissioned; externally peer reviewed.

ORCID iD

Corrado Tagliati http://orcid.org/0000-0002-4630-1090

\section{REFERENCES}

1 Amini B, Valenzuela RF, Bird JE, et al. Osteoid tumors of bone. Semin Ultrasound CT MR 2021;42:134-49.

2 Somma F, Stoia V, D'Angelo R, et al. Imaging-Guided radiofrequency ablation of osteoid osteoma in typical and atypical sites: long term follow up. PLoS One 2021;16:e0248589.

3 Hashemi J, Gharahdaghi M, Ansaripour E, et al. Radiological features of osteoid osteoma: pictorial review. Iran J Radiol 2011;8:182-9.

4 Campanacci L. Osteoid Osteoma. In: Picci P, Manfrini M, Fabbri N, et al, eds. Atlas of musculoskeletal tumors and Tumorlike lesions. Springer, Cham, 2014. 
Copyright 2021 BMJ Publishing Group. All rights reserved. For permission to reuse any of this content visit https://www.bmj.com/company/products-services/rights-and-licensing/permissions/

BMJ Case Report Fellows may re-use this article for personal use and teaching without any further permission.

Become a Fellow of BMJ Case Reports today and you can:

- Submit as many cases as you like

- Enjoy fast sympathetic peer review and rapid publication of accepted articles

Access all the published articles

Re-use any of the published material for personal use and teaching without further permission

Customer Service

If you have any further queries about your subscription, please contact our customer services team on +44 (0) 2071111105 or via email at support@bmj.com.

Visit casereports.bmj.com for more articles like this and to become a Fellow 